\title{
ALGUNAS OBRAS DESCONOCIDAS DE MANUEL TOLSA
}

\section{P O R}

FRA N CXSCO DE TA MAZA

\begin{abstract}
Wadie desconoce las grandes obras arquitectónicas o escultóricas del célebre artista Manuel Tolsá, estudiadas, más o menos bien, en libros y revistas, y recopiladas en su mayoría por don Alfredo Escontria en su interesante follato: Breve estudio de la obra y personalidad del arquitecto y escultor don Mankel Tolst, editado en 1929, al cual debemos añadir la obra de dop Diego Angulo Iñiguez Planos de América y Filipinas, Sevilla, 1939, que consigna varios proyectos arquitectónicos y noticias desconocidas.

Sin embargo, otras obras menores del ilustre valenciano han sido olvidadas o no son conocidas, por haber permanecido en proyecto, por haberse destruído, o pqr haber quedado en manos de particulares. Presento aquí algunas de ellas : los planos de un cementerio modelo; los planos de una oficina del Real Apartado; noticias de un cuartel; dos obras del camino de Toluca; una pirámide conmemorativa; un monumento sepulcral; dos proyectos de altares; la documentación de unos muebles; una obra de escultura, y pruebas de una falsa y repetida atribución de altares y esculturas que nunca ejecutó.
\end{abstract}


Si bien ya Manuel Tolsá no nos merece en la actualidad la ingenua y exagerada admiración que se le tributó en vida y durante todo el siglo pasado, pues no fué un artista siempre original en sus obras más importantes, su vigorosa personalidad, su actividad y su enorme labor artística en México, le deparan un lugar privilegiado en la Historia del Arte de América.

No hablo aqui de las dos piras funerarias que erigió para los arzobispos Núñez de Haro y Lizana, porque están incluídas, con su documentación e ilustraciones, en mi libro en prensa Las Piras Funerarias en Méxica.

Agradezco al señor Heinrich Berlin su gentileza en proporcionarme algunos datos de sus investigaciones en el Archivo General de la Nación.

Plano de un Cementerio Modelo

Desde el año de 1793 el virrey conde de Revillagigedo habia prohibido que se enterrasen cadáveres en las iglesias, pero era tanta la costumbre de hacerlo, que no logró se cumpliesen sus mandatos. Igual cosa ordenaron los virreyes Iturrigaray y Garibay, aunque con el mismo resultado. Sin embargo, Iturrigaray pudo obtener que se aprobase el proyecto de construir un cementerio general, "ventilado", en las afueras de la ciudad de México y que sirviese de modelo para las demás poblaciones de la Nueva España.

Los planos fueron encargados a Manuel Tolsá, quien los entregó el 2 de mayo de 1808 con el título de "Modelo de Planos para la construcción de Cementerios extramuros de las poblaciones". El virrey los envió al presidente de la Real Academia de San Carlos, el marqués de San Román, para que fuesen aprobados $y$ se tomasen copias. El 28 del mismo mes contestó el marqués diciendo: "Luego que recibi el superior oficio de V. $E$. de 23 del corriente con el perfil de cementerios que lo acompaña, mandé se pasase a la Real Academia para que se saquen de él las diez y seis copias que V. E. quiere, y concluidas éstas las dirigiré a V. E."

El 6 de agosto podía ya el marqués de San Román escribir: "Conforme al superior oficio de. V. E. acompaño los diez y seis ejemplares del Plan de Cementerios que V. E. me remitió para el efecto, executados por el Director Dn. Manuel Tolsá, con otros seis del que inventó el mismo, a fin de que puedan servir en las poblaciones pobres y de corta extensión". 
Pero no se hizo nada. En 1809 el arzobispo-virrey don Franciseo Xavier Lizana volvía a encargar a don Ambrosio de Sagarzurieta que se encargase del asunto. Sagarzurieta eligió sitio, juntó dinero, se movió ctanto pudo, pero tampoco logró que se construyera. En carta a Lizana, de 18 de noviembre de 1809, le explica: "Hemos decidido que el Cementerio se construya no lejos del Santuario de Ntra. Sra. de los Angeles y he hecho levantar por Don Manuel Tolsá los planos ${ }^{x}$ que conserva el Señor Gobernador de la Mitra, con el cálculo y presuptrestos de la obra; al pasar a tratar de los arbitrios para los grandes costos calculados, que en la mayor parte deberían recaer sobre este público, nos hallamos embarazados y detenidos por las circunstancias de la Monarquía, que de día en día se han ido poniendo más críticas, y sobre ser los menos a propósito para acabar de vencer la repugnancia de las gentes a este proyecto, exigen imperiosamente de nosotros toda clase de socorros para que por vía de préstamos patrióticos, ya de donativos, ya de contribuciones forzadas, así para armar este reino como para arrojar de la antigua España a nuestros enemigos los franceses, objetos ambos preferentísimos, que serían tanto menos atendidos cuanto más se exigiese y expendiese en la construcción del proyectado Cementerio..."

Mientras tanto las diez y seis copias se habian enviado a las principales ciudades, como consta por los recibos de ellas en el expediente, pero ninguna autoridad, ni civil ni eclesiástica, movía pie ni mano para su construcción.

En el año de 1814 hay una "Representación del Serior Intendente de México sobre los perjuicios que se seguirán a la salud pública de enterrar los cadáveres en las iglesias y cementerios de ellas" y el secretario del despacho decia al virrey Calleja que era indispensable "que se realice el establecimierito de Cementerios provisionales entretanto que se construyen permanente y con la decencia y decoro correspondiente". Todavia en 1820 hay un nuevo expediente "sobre que se lieve a efecto la determinación de que se construya un Cementerio para esta cicudad", en el que dice el fiscal que lo firma que "está instruido de que sobre este punto hay un expediente" y de que el cementerio no se hizo por "no haberse acordado (llegar a un acuerdo) las potestades superiores secular y eclesiástica".

Pero hay más. En 1824 el sindico don Juan Francisco de Azcárate escribia que en 1821 el arquitecto don José Paz había hecho "un hermoso

1 O miente el seäor Sagarzurieta o mandó bacex a Tolsá nnevos planos, puea ya se vió que este los habia entregado un año antes. 
plano" de cementerios, al cual el Ayuntamiento ni siquiera le habia dado las gracias, y que él había propuesto, a pesar de todo, que se gravasen las boticas, que ran más de veinticinco y el aguardiente, para que pudiera llevarse a efecto el proyecto de Paz. Del mismo año existe otro plan del arquitecto José Perovani, a quien el Ayuntamiento sí dió las más expresivas gracias al presentarlo, y en el cual dice que adjunta el diseño y su explicación (esta última existe en el expediente que voy estudiando) y que "ha ideado y delineado y para cuya ejecución, caso que V. E. la estimase conveniente, en todas o en algunas de sus partes, daré las instrucciones que mis limitados conocimientos y notorio celo por el bien común me sugieran, como hice en lo de la Habana, que dirigí y adorné hasta su cumplimiento". 2

En resumen, Manuel Tolsá hizo los primeros planos de cementerios generales, "modelos" para todas las ciudades de México, planos que fueton olvidados por circunstancias políticas y económicas y falta de acuerdo de las autoridades $y$ suplantados por otros que tampoco llegaron a construirse. Queda tan solo el proyecto, el bello dibujo del proyecto, perdido en los viejos y venerables papeles del Archivo General de la Nación.

Consta el proyecto de un atrio amplísimo, con una gran cruz de piedra en el centro, cuyo pedestal se parece mucho al de las cruces del atrio de la catedral. Va luego la capilla, precedida de un pórtico de orden dórico, sostenido por seis columnas. La capilla, intencional y novedosamente tiene su entrada principal hacia los campos de entierro y no hacia el atrio; a los lados tiene otras dos entradas, que se abren frente a las galerias de los extremos del pórtico. Diversas habitaciones para el uso del cura y sacristán y menesteres eclesiásticos se agrupan a izquierda y derecha de la capilla. En el fondo cuatro grandes extensiones de tierra, divididas por calzadas y un centro circular, sirven para los sepulcros.

Todo el proyecto se adorna, cuidadosamente, de verdes y melancólicos cipreses, pintados por Tolsá con toda ternura, rodeando el atrio y el cementerio.

2 La documentación está en el tomo 2 de Ayuntamientos del A. G. N. Perovani fué también pintor; hizo el retrato del virrey Calleja en 1815. 
Cuando murió Tolsá, a pesar de haber sido el encargodo del proyecto modelo de cementerios fuera de las ciudades, $y$ de las prohibiciones de enterrar en las iglesias o en sus panteones, fué sepultado "de oculto", en secreto, en el de la Santa Veracruz, su parroquia, como consta en su partida de defunción: "1816.-Parroquia de la Santa Veracruz.-México.Libro 3. Defunciones de Españoles.-Foja 211, No 33. El Sr. Don Manuel Tolsá.-En veinticinco de Diciembre de mil ochocientos diez y seis se le dió sepultura eclesiástica, de oculto, en el Campo Santo de esta Parroquia de la Santa Veracruz a el cadáver de Don Manuel Tolsá, español, de sesenta años, natural de la Villa de Enguerra en el Reino de Valencia, casado con Doña Luisa Sanz Tẻllez Girón. Recibió los Santos Sacramentos; testó, y para que conste to firmé. M. M Fran ${ }^{\infty}$ Castro Zambrano. (Rúbrica.)" 3

Oficinas eat el Real Apartado

En 1810 se hizo necesario construir la oficina del beneficio de tierras $y$ arreglos y reparos en el edificio del Real Apartado, para lo cual el Superintendente de la Casa de Moneda, don Francisco Fernández de Córdova, marqués de San Román, encargó a Tolsá los planos y el presupuesto đe las obras. El 8 de agosto presentó el arquitecto el "Presupuesto del costo que poco mám 0 menos tendrá la execución de la nueva oficina del beneficio de tierras del Real Apartado de Oro y Plata con inclusión de Homos Castellanos, Fuelles, Arrastras, Lavaderos, Tanques y demás pormenores que se expresay adelante e inđíca el adjunto plan." El cálculo fué de 38,830 pesos, incluídos 1,000 que se deberian de pagar a Tolsé.

No comenzaron las obras inmediatamente por causa de la revolución de Independencia, sino hasta fines de 1811. E1 9 de septiembre de ese año, en la Memoria semanaria número 22, se lee: "Se han cargado 500 pesos a Dn. Manuel Tolsá como director de la obra, expresando por su tecibo ser a buena cuenta de los un mil que importa la dirección de toda ella, según está puesto en el presupuesto aprobado".

Naturalmente que el clásico Tolsá estaba muy a đisgusto con el edificio batroco en que iba a trabajar, asi como con las descuidadas costumbres

3 Agradezeo al señor Pablo Zayas Jazero, descendiente de Tolsá. la copia de este documento. 
mexicanàs de poner dondequiera macetas en desorden. El 30 de octubre de 1812 puso la siguiente carta al marqués de San Román: "Como Arquitecto del Real Apartado no puedo menos que hacer presente a V. S. I. los perjuicios que pueden causar a su edificio cualquier inadvertencia. El patio principal, cuyos corredores están sostenidos con columnas de piedra colocadas a unas largas distancias de una a otra y con planchas de madera, sufren con mucho perjuicio un peso enorme a causa de unos arreates $o$ cajones de mampostería llenos de tierra en donde hay plantados varios árboles y flores, y a más sufren las maderas de dicho corredor la humedad que es consiguiente a sus riegos, los que uno y otro ofrecen la destrucción de dicho corredor, por lo cual deben quitarse dichos cajones y más cuando la misma amplitud del corredor, sin que en nada le ofendan, pueden colocarse cantidad de macetas que satisfagan el gusto de los que ocupan aquellas viviendas, en virtud de lo cual V. S. I. se servirá resolver lo que juzgue conveniente. Dios guarde a V. S. I. muchos años. México y oct. 30 de 1812. Manuel Tolsá. (Rúbrica.) Claro está que el marqués ordenó de inmediato, en la misma carta de Tolsá, que se quitasen.

El 2 de marzo de 1813 estaba concluída la obra, que resume el clavero don Joaquín Maria Casarín en su informe de junio del mismo año: "Se fabricó de nuevo el departamento de fundiciones y laborío de tierras desde sus cimientos; se colocaron en ella tres Arrastras, se le hicieron los Tanques y Planilleros necesarios para labrar y dos Hornos Castellanos con sus correspondientes Fuelles, colocados en los mismos términos que los de los órganos. Como anexo a esta oficina se habilitó el patio para el beneficio de azogue, enlosándolo y haciendo en él la pila o fuente de agua con su correspondiente tanque para labrar las orruras y demás que produce aquel beneficio. Se hizo como esencial para este efecto el lavadero principal con su molinete. Se fabricó de nuevo una bodega que sirve para la custodia del azogue; se hicieron dos habitaciones, una accesoria y de la cochera del apartador se hizo el cuarto en que se depositan los instrumentos y demás utensilios del beneficio de tierras.

"La bodega principal en que se disponen las operaciones prolixas y delicadas del apartado, estaba antes de ahora con alguna estrechez, y se amplió por un extremo, todo lo que ocupaba la pieza del antiguo ensaye y por el otro lo correspondiente al zaguán, que se removió al lugar donde hoy se halla. Se levantó el piso del patio; se hicieron los lugares comunes; se habilitó de nuevo la pieza del ensaye; se hicieron de las cocheras, una para el apartador y otra para el carro en que se conducen los metales, apro- 
vechando para esto el claro de los arcos que se hicieron bajo el corredor donde se formó una capilla para colocar la Imagen de Ntra. Sra. de Guadalupe como patrona de estas oficinas; se batieron las dos escaleras de las viviendas del Apartador y su ayudante; en las fundiciones se echaron vidrieras; se abrió al tesoro comunicación para la fundición de tierras; se levantaron los pretiles de la azotea que ve al patio principal y se hizo la fuente de agua que está en la calle de las Arzinas. Finalmente se blanqueó el edificio por su parte interior y por la exterior se aplanó y pintó toda su fachada".

A la muerte de Tolsá, para nuevos reparos de la casa, se llamó al arquitecto don Joaquín de Heredia.

El proyecto consta de un alzado de la oficina de fundición, con su corte interior, mostrando la gran sala en la cual se aprovechó parte del edificio anterior, los dos cuartos con ojos de buey, y fueron hechos los tres tramos siguientes con ventanas cuadrangulares. El plano muestra el salón, en negro lo antiguo y en rosa to hecho por Tolsá. Frente a la oficina están, de izquierda a derecha: los lugares comunes, una bodega, la entrada y tres habitaciones para fuelles y una habitación que quedó como antes. A la izquierda del patio se hizo una galería cubierta, con el techo sostenido por dos pilastras.

No todo lo que dice el clavero en el informe anterior está en este plano, pues faltan varias dependencias y la capilla, formada en la galería, construcciones todas posteriores al proyecto inicial.

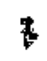

Noticias del Cuartel de Peredo

El cuartel de Peredo, llamado así por haberse construído en la antigua calle del Puente de Peredo, que aún conserva su nombre, fué destruído hace algunos años para urbanizar toda esa zona del actual mercado de San Juan. No quedan ni rastros, ni litografias, ni fotografias. Tan sólo el romántico recuerdo de los jóvenes militares que salian de allí a cortejar a la famosa Güera Rodríguez.

No se sabía que el cuartel de Peredo habia sido obra, en parte, de Manuel Tolsá, hasta que se hizo la utilisima Guia del Archivo Histórico de

4 A. G. N. Ramo Casa de Moneda, tomo 465. 
Hacienda, en donde se consigna, en el legajo 98-2, un documento sobre ello. En efecto, es una mínima parte de las cuentas de construcción del cuartel. Comienza con la "Memoria de los gastos causados en la construcción del Quartel de Caballería sito en el Puente de Peredó a dirección del Señor Maestro de Arquitectura Dn. Manuel Tolsá", que corre de diciembre de 1808 a junio de 1809 , firmadas y rubricadas las rayas por Tolsá.

En agosto de ese año dejan de aparecer las firmas de Tolsá, substituídas por las de José Maria de Echegaray y una explicación de Miguel Costansó sobre una cuenta incompleta. Esto quiere decir, sin que sepamos por lo pronto la causa, de que la dirección corría desde ese mes a cargo de Costansó.

Por otra parte, Tolsá trabajó mucho en edificios militares, $y$ sin sueldo, cono lo decía en 1815 el conde de Casa de Heras a la Academia de San Carlos: "Tampoco ha llevado estipendio alguno las diversas ocasiones que por vuestro virrey se le ha comisionado para ampliación, compostura u ordenación de diversos quarteles militares." 5

Fuente del Camino de Toluca

En 1791 se decidió el virrey Revillagigedo a construir el camino de México a Toluca, para lo cual comisionó al ingeniero Manuel Agustín Marcaró para que "lo reconociese, dictara sus obras y avaluase su costo". Mascaró estudió la obra y presentó su proyecto, en el cual el camino debería pasar por Santa Fe, Cuajimalpa, Tianguillo, Cruces, Llano de Salazar y Lerma, con un costo de 102,330 pesos. Se pregonó la postura, por voz de pregonero, en México, Guadalajara, Valladolid y Toluca, y como a nadie se le ocurrió abaratar la construcción se le dió a Mascaró, nombrando segundo director a Diego Garcia Conde.

En 1793, ya adelantada la obra, se quișo conmemorarla por medio de una fuente en el arranque del camino, que era donde hoy es la calle de Serapio Rendón, esquina con Gómez Farías. El proyecto se encomendó a Tolsá, al cual se le pagaron -quinientos pesos. El 6 de noviembre de ese año dirigió el virrey dos cartas, una al administrador del camino y la otra a Tolsá, que dicen: "Don Jacobo García.-Entregará V. M. a Dn. Manuel Tolsá quinientos pesos en que se ha convenido construir el pedestal que

5 Méritos y Serviciós de Manuel Tolsá, en Anales de este Instituto, núm. 12. pág. 34.. por Manuel Romero de Tetreros. 
se ha de erigir a la entrada del camino de Toluca, a fin de que inmediatamente ponga a execución dicho Monumento". "Don Manuel Tolsá.Acompaño a V. M. la orden para Dn. Jacobo García, administrador de la importante obra del camino de Toluca a fin de que entregue a V. M. los quinientos pesos en que se ha convenido construir el pedestal que se ha de erigir a la entrada del camino, incluyendo a V. M. al mismo tiempo los dibujos, con mi rúbrica, a que ha de arreglarse dicho Monumento que pondrá en execución inmediatamente". 6

Estos dibujos deben ser topográficos. Existe una copia de un mapa parcial de la ciudad de México donde se muestra el lugar en que está la fuente o "pedestal" y el principio del camino. En esta copia, a la izquierda, está un torpe dibujo del proyecto de Tolsá, y arriba la inscripción que llevaba:

EN EL REYNADO DEL SEÑOR DON CARLOS IV

EL EX'. SEÑOR DON JUAN VICENTE GUEMES PACHECO

DE PADILLA CONDE DE REVILLAGIGEDO VIRREY

GOBERNADOR Y CAPITAN GENERAL DE ESTA N. E. EN

FAVOR DE LA REPUBLICA COMODIDAD Y PARA ADOR-

NO DE ESTA IMPERIAL CIUDAD DE MEXICO $Y$ RECREO

DE SUS HABITANTES MANDO A SU ILUSTRE AYUNTAMTEN-

TO ABRIR ESTE CAMINO Y FABRICAR ESTA FUENTE CU-

YAS OBRAS SE CONCLUYERON EL AÑo DE 1794.

La fuenté fué destruída en una de las muchas planificaciones nuevas de la ciudad de México, quedándonos tan sólo la copia del proyecto. " i

Obelisco del Camino de Toluca

Cuando el ingeniero Mascaró terminó el camino de México a Toluca, en 1795, rindió un informe al virrey el 11 de marzo de ese año que es a la vez un compendio histórico y un balance económico de la obra. Añade en él algunas cosas que faltaban, como la reforestación de ciertas zonas y el

6 A. G. N. Ramo de Caminos y Calzadas, tomo 13.

7 El mapa está en la Dirección de Estudios Geográficos, de Tacubaya, número 974 y el dibujo que reproduzco es una copia fiel del proyecto que lleva el mapa hecha por el ingeniero don Enrique $A$. Cervantes, a quien agradezco, ademís, ta comunicación de la existencia del mapa. 
que se erigiera un obelisco, a medio camino, para eterna memoria de la empresa.

"Su mérito -dice- debería esculpirse en otra Ánscripción, colocada al pie de un obelisco que deberá ponerse en el Monte de las Cruces, por tres motivos principales: el primero, por ser el punto más elevado de la carrera; el segundo, por ser el mismo donde se dió principio a esta obra; el tercero, por hallarse justamente en el centro de la distancia que media entre la Ciudad de México y la Villa de Toluca; por si acaso V. E. tuviere a bien la construcción de este monumento, remito un diseño que para este fin se mandó delinear al Académico de Escultura don Manuel Tolsá".

El 3 de abril el Secretario del Despacho, don Bernardo Bonavia, declaraba al virrey que "no hallaba embarazo en que se pusiera" y el administrador don Jacobo Garcia explicaba: "el obelisco en lo alto del monte de las Cruces, aunque parece cosa inconducente, no lo es en la realidad, porque en él conviene se describa, para perpetua memoria del Superior Gobierno de V. E. y se grave en una inscripción su respetable nombre, después del de Nuestro Católico Monarca y por tiltimo el del señor Conde de la Contramina, a fin de que llegue a la posteridad la justa y bien merecida fama del generoso suplemento que dió para la obra..."

El obelisco fué aprobado, pero no sabemos si fué construído. Faltan los documentos al respecto $y$ no hay noticia impresa de ello en las numerosas obras de viajes o descripciones pintorescas que se hicieron el siglo pasado.

El dibujo de Tolsá consta de un zócalo, muy movido de líneas, con la cartela para la inscripción en el centro. La pirámide, muy esbelta, tiene en su base un reloj de sol, que buen servicio hubiera hecho a los lentos caminantes de la Nueva España de fines del siglo xviı1. ${ }^{8}$

Pirámide en la Cuesta de Barrientos

En la última visita que el virrey don Miguel José de Azanza hizo al aún inconcluso desagüe del Valle de México, en abril de 1799, al regresar por la cuesta o "puerto" de Barrientos, "vió no sin admiración qute un paso tan transitado y necesario para cuantos entran o salen a tierra adentro esté tan incómodo y molesto que apenas pueda pasar carruaje

8 Diseño $y$ documentación en el Archivo General de la Nación, ramo de Calzadas y Caminos, vol. 19. 
alguno sin riesgo $\mathrm{y}$ con suma incomodidad por lo pendiente $\mathrm{y}$ desigual del piso".

Ordenó inmediatanente que fuesen llamados ingenieros y arquitectos para su arreglo, pero su remoción a España en 1800 paralizó todas las actividades. En 1803 el virrey Iturrigaray decía que "ha sabido que en poder del Justicia de Cuauhtitlán existe una cantidad de dinero que debe invertirse en la composición de la cuesta de Barrientos..."; encargó a Ignacio de Castera la obra, y al "celo insigne" de don Cosme de Mier, la administración.

Se pidió a Manuel Tolsá, aun antes de acabar los trabajos, que hiciese una pirámide conmemorativa, para colocarla en el lugar más visíble de la cuesta. Tolsá presentó su proyecto (que por desgracia no existe) con el siguiente cálculo: "El costo que considero tendrá la Pirámide, siendo su zócalo de piedra chiluca y el resto de cantería, situada donde se determinó últimamente, y arreglada al tamaño que expresa el adjunto y último dibujito, en consideración a que los canteros deben costar más que en México y a que dicha piedra debe conducirse desde Ntra. Sra. de los Remedios hasta la cuesta de Barrientos, que es donde se ha de situar, es el de ciento cincuenta pesos, sin contar con sus dos lápidas. Si éstas fuesen de piedra chiluca, con inclusión de su costo, el labrado, grabado de sus letras, su conducción y pintado de negro al óleo, costarán ochenta pesos las dos y si fuesen del mármol blanco de Villería costarán ciento veinte.-Agosto 21 de 1804".

Las inscripciones de las lápidas están en castellano y en latín.

La española es la siguiente:

$$
\text { . }
$$

"E1 Exmo. Señor

D. Joseph de Iturrigaray

Virrey de esta N. E.

Por el clement ${ }^{\circ}$ Carlos IV

Rey de España y de las Indias

Consultando a la comodidad pública

Hizo allanar esta áspera montaña

A costa de los circunvecinos

En $1^{\circ}$ de Agosto de 1804

Por comisión dada

Al Sr. D. Cosme de Mier y Trespalacios

Del Consejo de Su Maj.

Oidor Decano de esta $R^{1}$ Aud." 
Pero dos años después no se le habia pagado a Tolsá. E1 trece de mayo de 1806 escribia : "Don Manuel Tolsá, director de la Real Academia, con el más profundo respeto ante V. E. digo: que el difunto Sr. Regente de esta Real Audiencia D. Cosme de Mier y Trespalacios se sirvió encargarme la execución de una Pirámide con dos inscripciones, que se puso en el carnino y cuesta de Barrientos, a cinco leguas distante de esta capital, pero habiéndose conclúdo todo y faltando el móvil, que lo era dicho Sr. Mier y no habiéndoseme satisfecho doscientos diez y seis pesos que erogué de mi bolsillo en la Pirámide e inscripciones, según consta en el pormenor de la cuenta presentada e inserta en dicho expediente, sin incluir nada por el honorario de mi trabajo y viajes que hice a dicho sitio; por tanto a $V$. E. suplico tenga a bien mandar a quien corresponda se me satisfaga la indicada cantidad de los fondos de que se costeó esta obra y si no hur biere sobrante se colecte de los propios vecinos que la costearon, que es justicia, que juro y lo necesario, etc. Manuel Tolsá (Rúbrica)."

Esta "pirámide", hecha con dinero del propio bolsillo de Tolsá existe aún en su sitio, sobre el actual túnel del ferrocarril de Laredo, aunque con el suficiente descuido para estar sirviendo de apoyo a una inútil bar. da de piedra.

El tosco monumento que, ciertamente, no añade nada a la gloria artística de Tolsá, tiene forma de pentágono irregular, con remate de pirámide triangular; mide cuatro metros de altura, desde su base visible, hasta la cúspide; los lados mayores del pentágono tienen un metro y medio, y los menores treinta y tres centímetros; las placas, de marmol, miden noventa y cuatro centímetros de alto por sesenta y dos de ancho.

Altar en la Casa de Moneda

A principios del siglo xix, el antiguo altar de la capilla de la Casa de Moneda estaba destruyéndose, por lo que pensaron las altas autoridades de la rica institución cambiarlo por uno "moderno", encargándole el diseño a Manuel Tolsá. Entregó éste el proyecto el 22 de julio de 1803, con el siguiente oficio:

"Executándose el altar de la Capilla de la Real Casa de Moneda, según el dibujo adjunto, construyendo su mesa de altar y zoclo de piedra de chiluca, para precaber las resultas de la humedad, el altar de escayola y los adornos de los lados que completan el vacio del arco con las dos imágenes, uno y otro de estuco, tendrá de costo tres mil y quinientos pesos. 
Si dicho altar se quisiese construir de madera de cedro, con sus molduras y adornos dorados y el resto pintado jmitando de jaspes, costará dos mil pesos. Manuel Tolsá. (Rúbrica)".

Pasaron los años y el diseño permanecía archivado, hasta que en el año de 1818, dos años después de muerto Tolsá, el administrador de la Real Casa, don Manuel Lozada, lanzó un expediente desesperado que tituló: "Sobre que construya un Retabla o Colateral que corresponda al decoro del Santuario y al lustre del Rey, en la Capilla de esta Real Casa, y que sustituya al que en el dia se halla, lieno de defectos, apolillado e indecente y su imagen rota". Hizo también Lozada en este expediente el "cálculo prudencial" de la obra, que resultó ser, después de quince años, de 1,645 pesos solamente, a pesar de que las estatuas se encargarían a Pedro Patiño Ixtolinque, el conocido discípulo indígena de Tolsá. El cálculo es el siguiente, que por corto e interesante copio integro:

"Por la mesa del altar, de tres varas de largo, una y cuarta de alto, con basa y cornisa de piedra de chiluca y el centro de ladrillo estucado en blanco... . . . . . . . . "Por las gradas que reciben las columnas . Por dos columnas y pilastras de orden corintio, trabajadas primero de piedra en canteria y después estucadas, tendrán de costo, sin capiteles y basas, con tres y media varas de largo . "Por el marco o medio punto de la colocación del lienzo, de dos y media varas por una y media de ancho, estucado y de madera el marco, y de abrir y cerrar, tendría de costo . . . "Por la cornisa y frontis, formados de ladrillo de estuco sin los adornos

"Por los estucados de los lados, sin florones.

"Por vaciar y dorar los adornos de la mesa del altar y gradas.

"Por los capiteles y adornos de casetones de detrás de las estatuas.

"Por los adornos del frontis, friso, arquitrave y cornisa . -
"Por los adornos del medio punto que consta de una ráfaga y

"Por barnizarlo y pintarlo todo de blanco y sus correspondientes $100 \mathrm{ps}$. 120 ps.

80 ps.

90 ps.

200 ps.

80 ps.

65 ps.

60 ps. 100 ps.

190 ps.

290 ps. 100 ps. 
"Por las dos estatuas con sus colores al natural representando a San Juan y la Magdalena, y de mano de Patiño, a ciento veinticinco pesos cada una.

Demostración del costo total:

"Costo en blanco .

"Dorado y pirtura

"Lienzo y estatuas

$$
\begin{aligned}
& +. \quad .670 \mathrm{ps} \\
& 625 \text { ps. } \\
& 350 \mathrm{ps} \text {. } \\
& 1,645 \text { ps. }
\end{aligned}
$$

Lozada agregaba, para convencer al virrey, que "a la verdad, no parece propio de este Real Ingenio, un retablo lleno de defectos, adornado tan monstruosamente, y que, arreglado al pésimo gusto del tiempo en que se construyó, lejos de causar devoción, mueve a risa al pueril y al sensato a dolor" y que cuando habia misas o funciones religiosas se tapaba al pobre retablo con gruesas cortinas para que se ignorase su vergonzosa existencia.

E1 parrafillo es importante por ser la expresión de las ideas que se tenían, en la época del neoclásico, sobre los retablos dorados, barrocos o churriguerescos. Este de la Casa de Moneda debió ser barroco, pues el edificio se estrenó en 1734. Don Lucas Alamán diria años después, en sus Disertaciones, palabras tanto o más duras, mientras el clero y los arquitectos se encargaban de destruir los retablos sin piedad alguna, aunque a veces con razón.

No hay duda de que el altar de Tolsá se construyó, aunque por otro arquitecto, o quizás por Patiño Ixtolinque, pues en el citado expediente hay una apostilla de 16 de octubre de 1834 que dice: "Respecto de que a la fecha ya está hecho el colateral por piadosa donación de algunos individuos, yạ no tiene que informar en esto la Contaduria"."

Ya no existen ni el altar ni la capilla, destruídos, tal vez, en 1848, cuando la Casa de Moneda se cambió al Apartado y el edificio se reformó Exp. 5.

9 Archivo General de la Nación. Ramo de Casa de Moneda. Tomo 265. 
para su adaptación a oficinas públicas, o en 1862, cuando se instaló en él el Museo Nacional de Historia y Arqueología.

El proyecto está pintado a la actarela, en tinta azul, con ese fino dibujo que caracteriza a los profesores académicos.

Se compone de una mesa de altar, adornada con medallón crucial en el centro $y$ unos recuadros rectangulares con omamentación floral. Tanto la base como la parte superior de la mesa están compuestas de molduras fuertes y sencillas.

Tres escalones, adornados con laureles romanos, ascienden hasta un marco central, donde debía ir la pintura citada en el cálculo.

A los lados, dos zócalos, adosados a la apred, con dos columnas corintias romanas, sostienen el clásico entablamento, armonizando con las mismas molduras de la mesa del altar.

La cornisa se adorna con denteliones, y de ella arranca el frontón, formados por arcos rebajados, como en el altar de Santo Domingo, en cuyo centro se ostenta un elemento decorativo, la gran ráfaga de bronce con el emblema de la Trinidad.

Otros dos zócalos, a los lados de la mesa de altar, empotrados en el muro, llevan dos esculturas, sirviéndoles de fondo una ornamentación de medallones rectangulares con una flar estilizada, que se continúan en el remate, que sigue el movimiento cilíndrico del frontón.

En la planta hay dos tipos distintos, para escoger, de las molduras que debían hacer marco a toda la obra, llenando el espacio sobre el cual se debia construir.

La altura de todo el altar era de siete metros.

$$
5
$$

Un Proyecto de Altar

Existe en la Sección de Manuscritos del Museo Nacional un cartapacio titulado: "Catorce dibujos de Francisco Eduardo Tresguerras y un grabado de Montes de Oca", pero en realidad son trece dibujos de Tresguerras y el grabado es la pira funeraria que hizo Tolsá para el arzobispo Núñez de Haro y Peralta.

El primero de los dibujos no es del celayense. Es un altar neoclásico que no dudo en atribuírto a Manuel Tolsá, por el estilo depurado, por 
las correctas proporciones, por la manera fría y fina de dibujar, por el ambiente, en fin, que conocemos en los dibujos y acuarelas de Tolsá y de los profesores académicos. Todas estas características son muy diferentes en Tresguerras, cuyos proyectos y realizaciones tienden al barroco y cuyo dibujo es ondulante y nervioso, mucho mejor y más cálido que el de Tolsá. Además, este proyecto se parece al de la Casa de Moneda, de que he hablado antes, no sólo en la pureza y detalles arquitéctónicos, sino en el dibujo, en la tinta, en el sombreado, y hasta en el papel, que es el mismo que el del proyecto anterior, más grueso que el usado en los demás dibujos del cartapacio.

En este altar la mesa es pequeña, adomada con un recuadro de molduras sencillas y un medallón en el centro. A los lados, ménsulas acanaladas con ornatos de medallones como clavos.

Sobre dos zócalos, con recuadros vacios, se sostienen las. columnas, de orden jónico romano, entre las cuales va la pintura principal del altar. Las columnas detienen el entablamento, que ostenta en el centro una nube con un busto del Eterno Padre.

Fl remate se compone de un gran arco de medio punto, en cuyo centro, sobre una base con estatuas en las esquinas, van pilastras pareadas que sirven de marco a otra pintura. Recuadros muy parecidos a los del proyecto de la Casa de Moneda, con flores estilizadas, ornamentan el remate, y en las enjutas dos grandes medallones-clavos hacen simetría con los de la mesa. Es el único elemento que puede aparecer desproporcionado.

A los lados de las columnas hay nichos para esculturas, con recuadros vacíos, rectangulares, que llenan, en posición vertical, el espacio del murc. Pilastras jónicas limitan el altar a los lados.

No sabemos, por ahora, para qué iglesia fué proyectada esta obra, ni tampoco si fué constrúda o si sólo quedó en el papel, olvidada y confundida con otros dibujos tan distintos.

¿Será el "Retablo" que hizo Tolsá, junto con otros proyectos para recibir su nombramiento de arquitecto en 1810 ? 


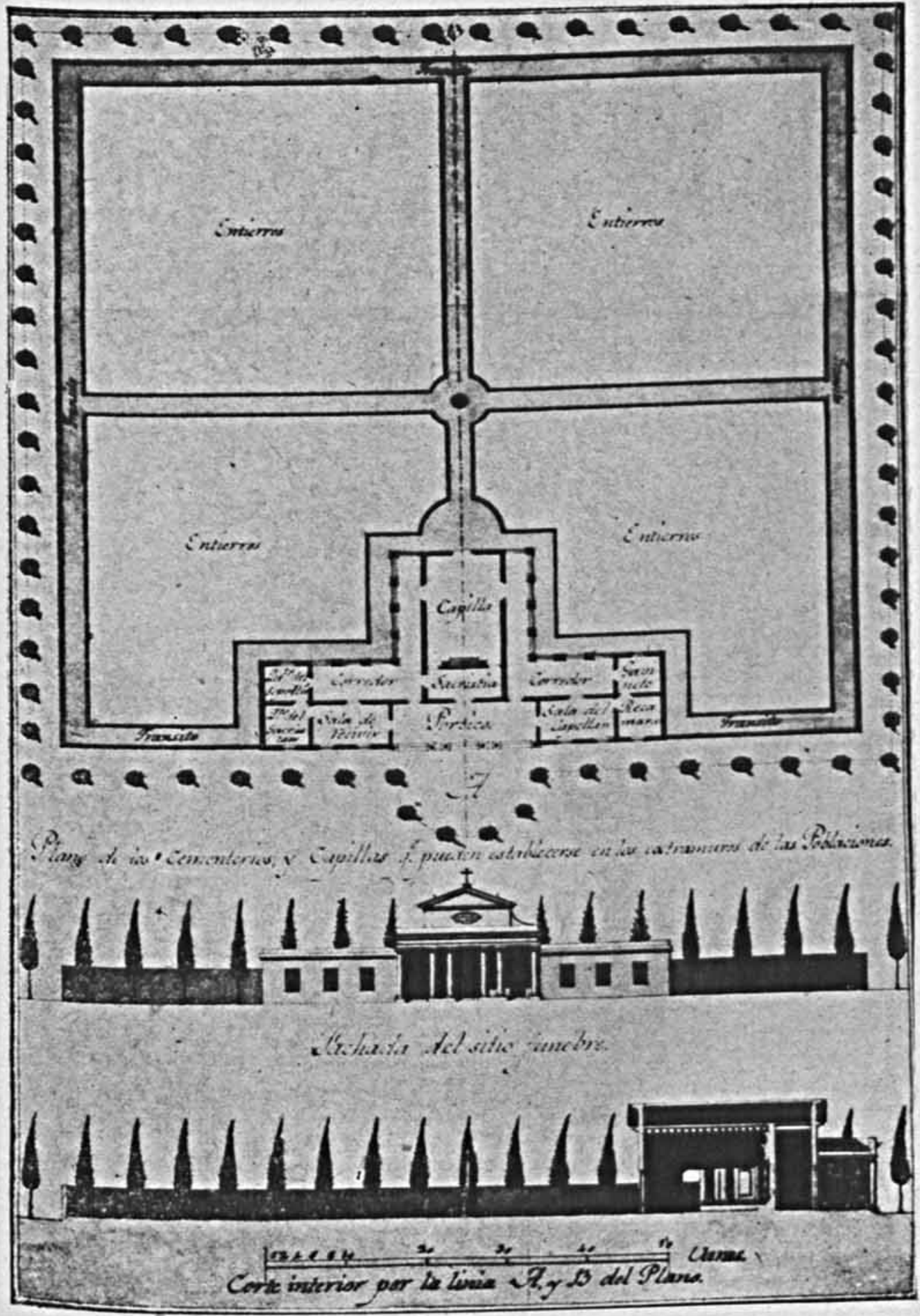

Fig. 1. Planta y alzado de Cementerio Modelo 


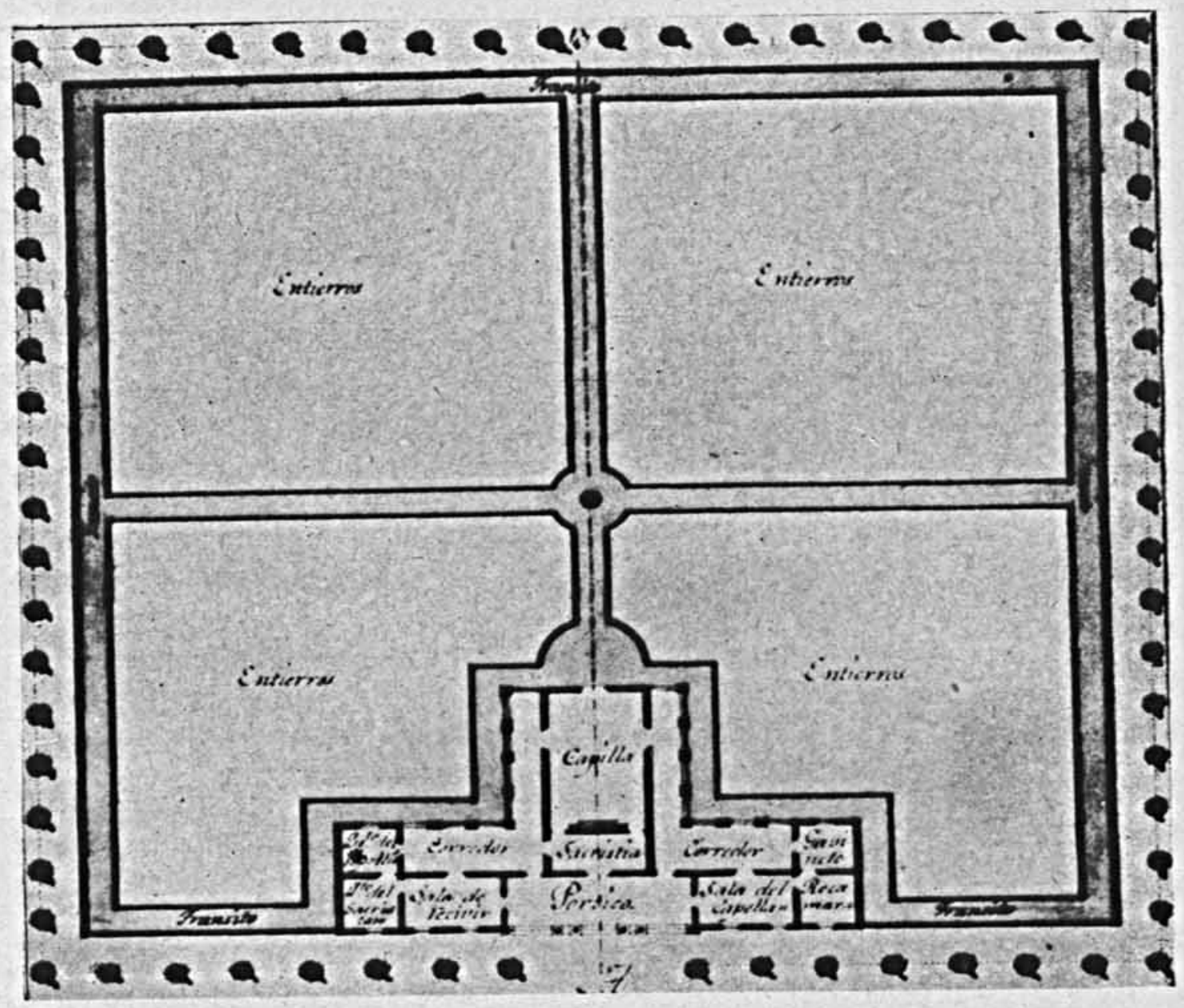

Fig. 2. Planta de Cementerio Modelo. Detalle 


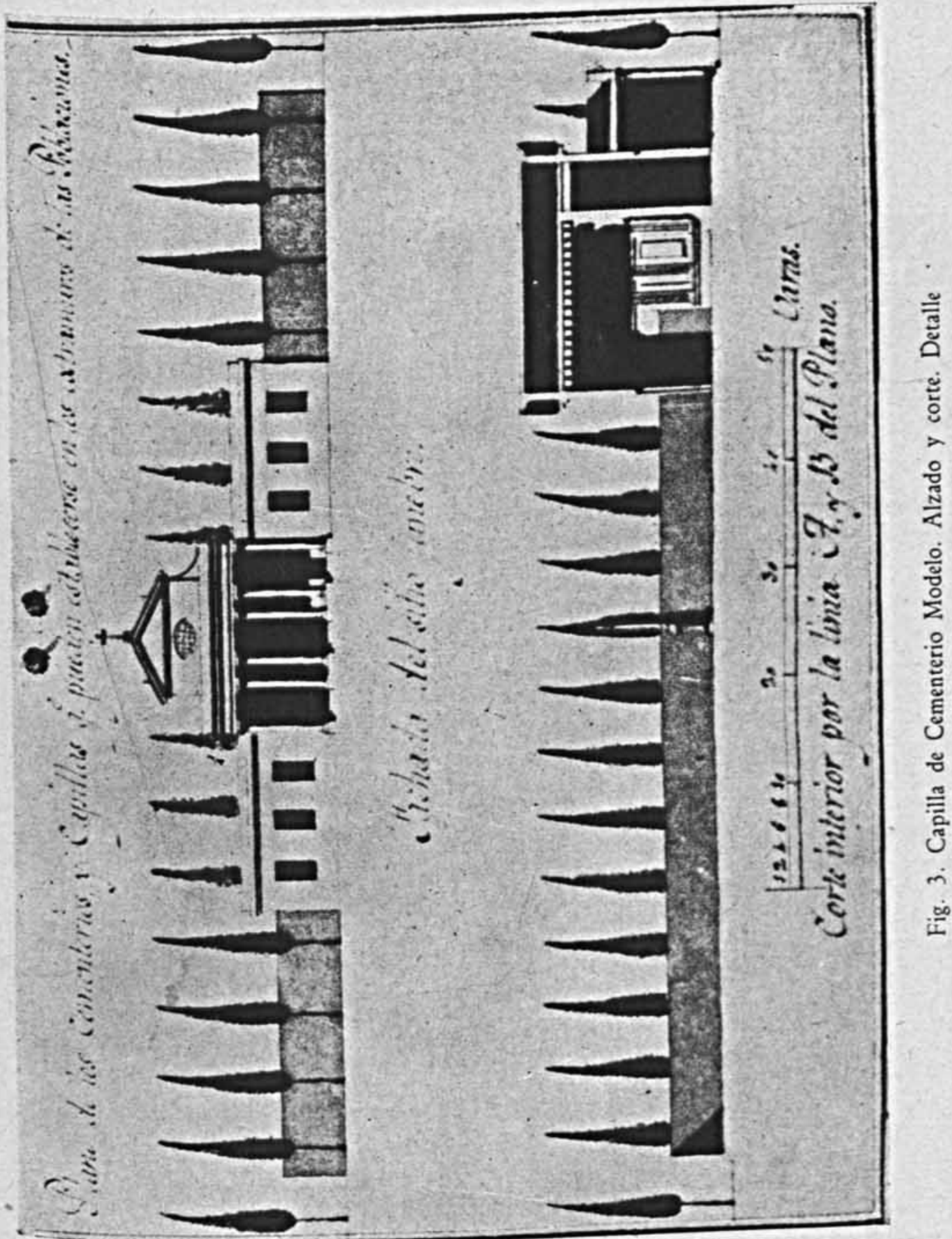


DOI: http://dx.doi.org/10.22201/iie.18703062e.1946.14.414

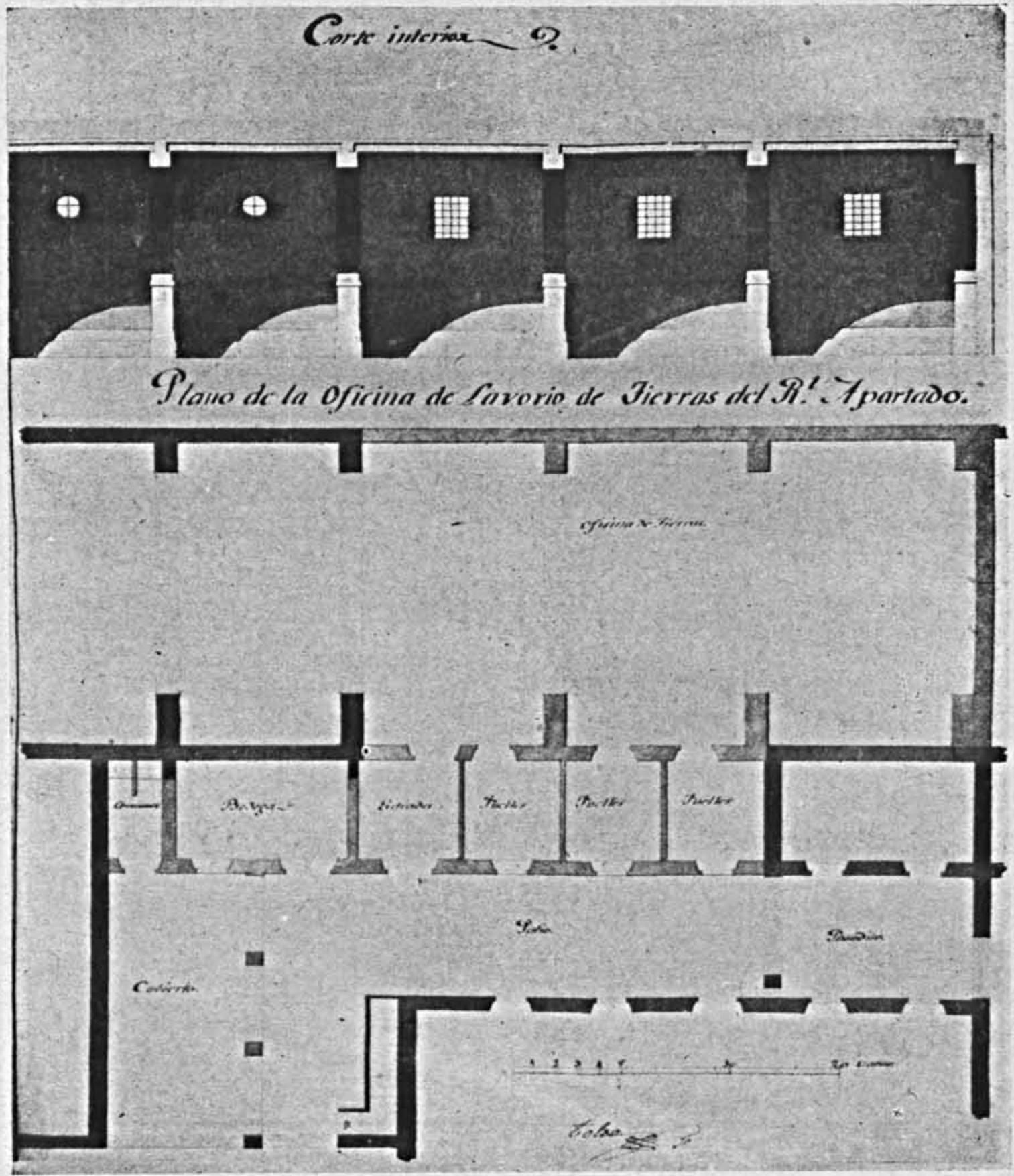

Fig. 4. Planta y alzado de oficinas en el Real Apartado 


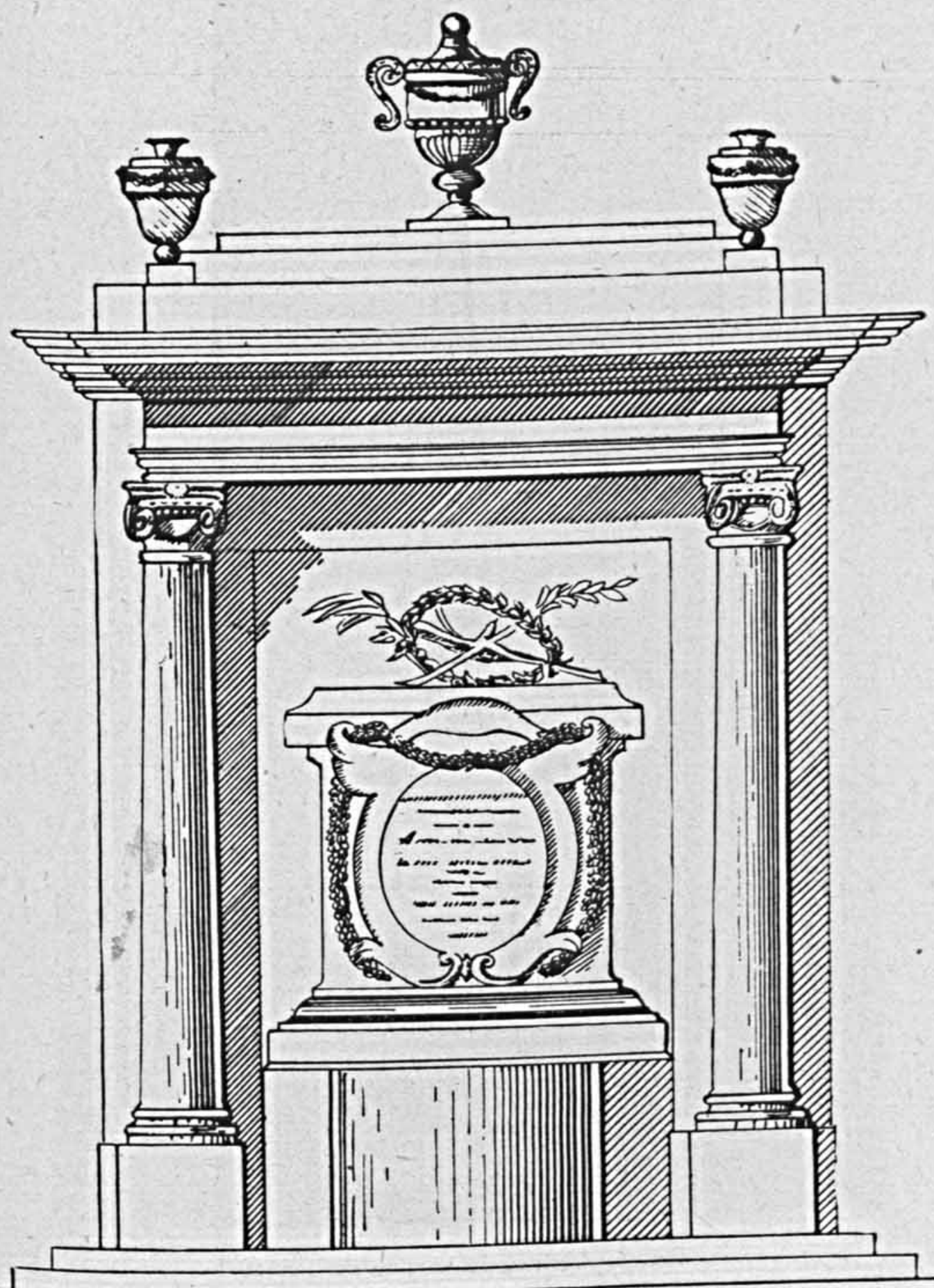

Fig. 5. Fuente del camino de Toluca 
DOI: http://dx.doi.org/10.22201/iie.18703062e.1946.14.414

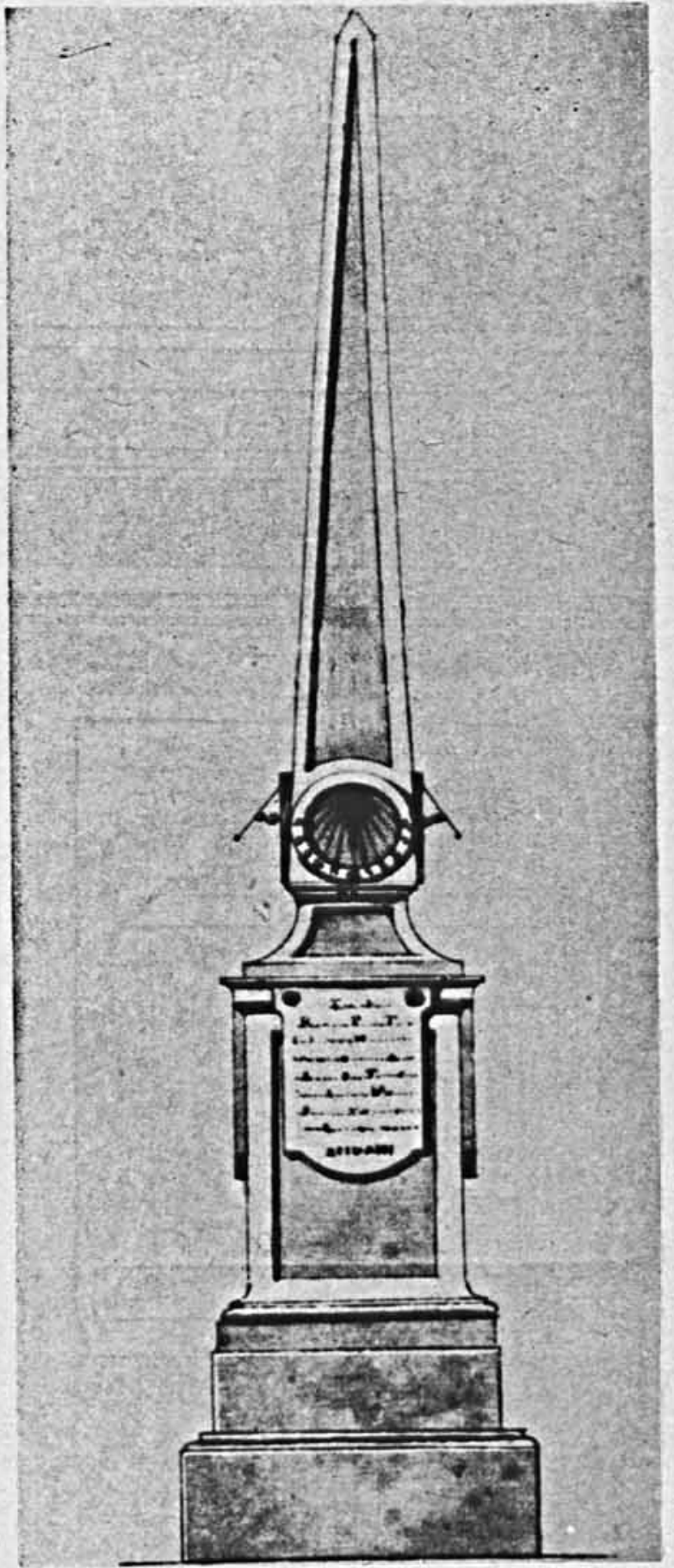

Fig. 6. Obelisco del camino de Toluca 


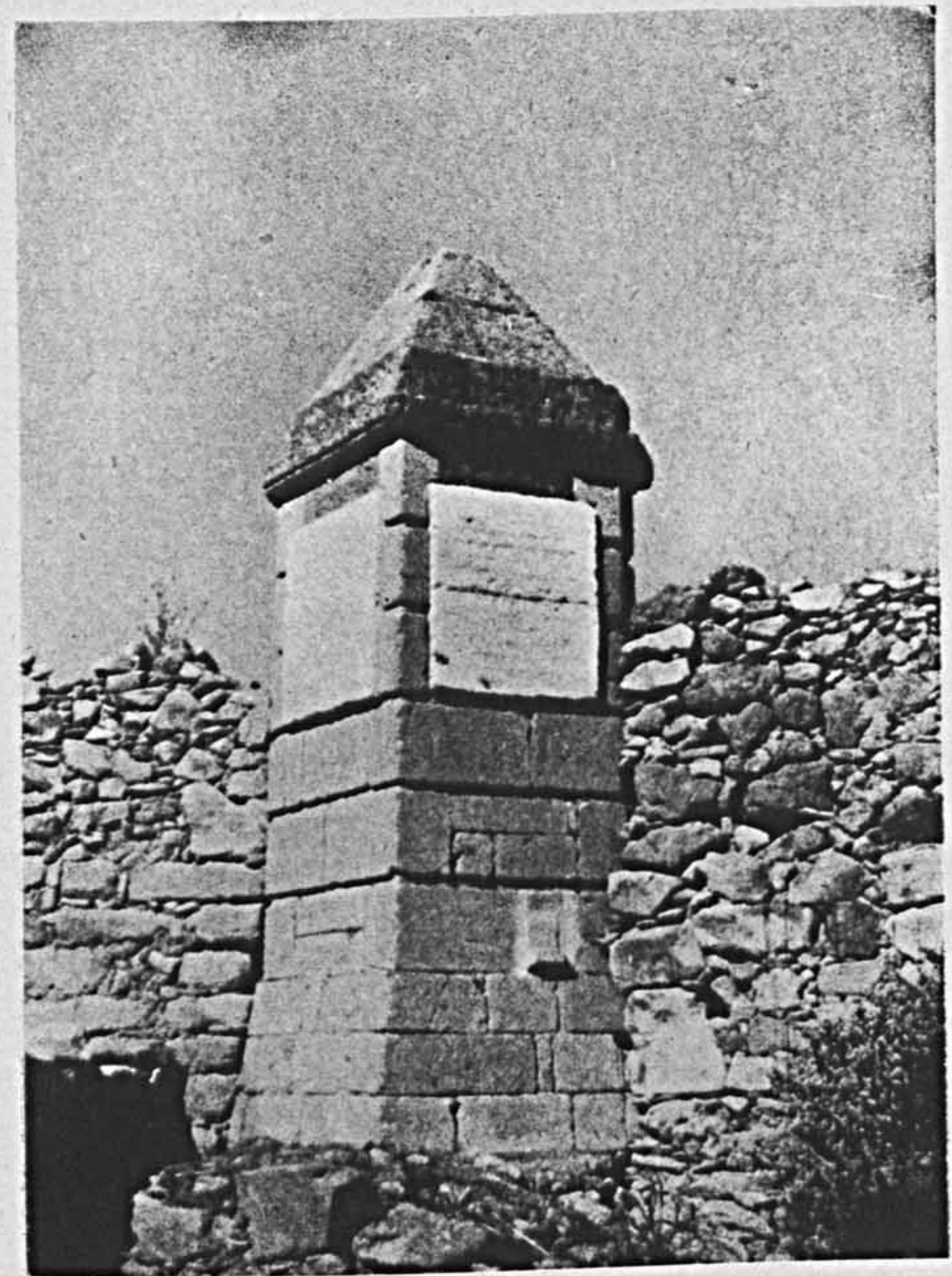

Fig. 7. Pirámide de la cuesta de Barrientos 
DOI: http://dx.doi.org/10.22201/iie.18703062e.1946.14.414

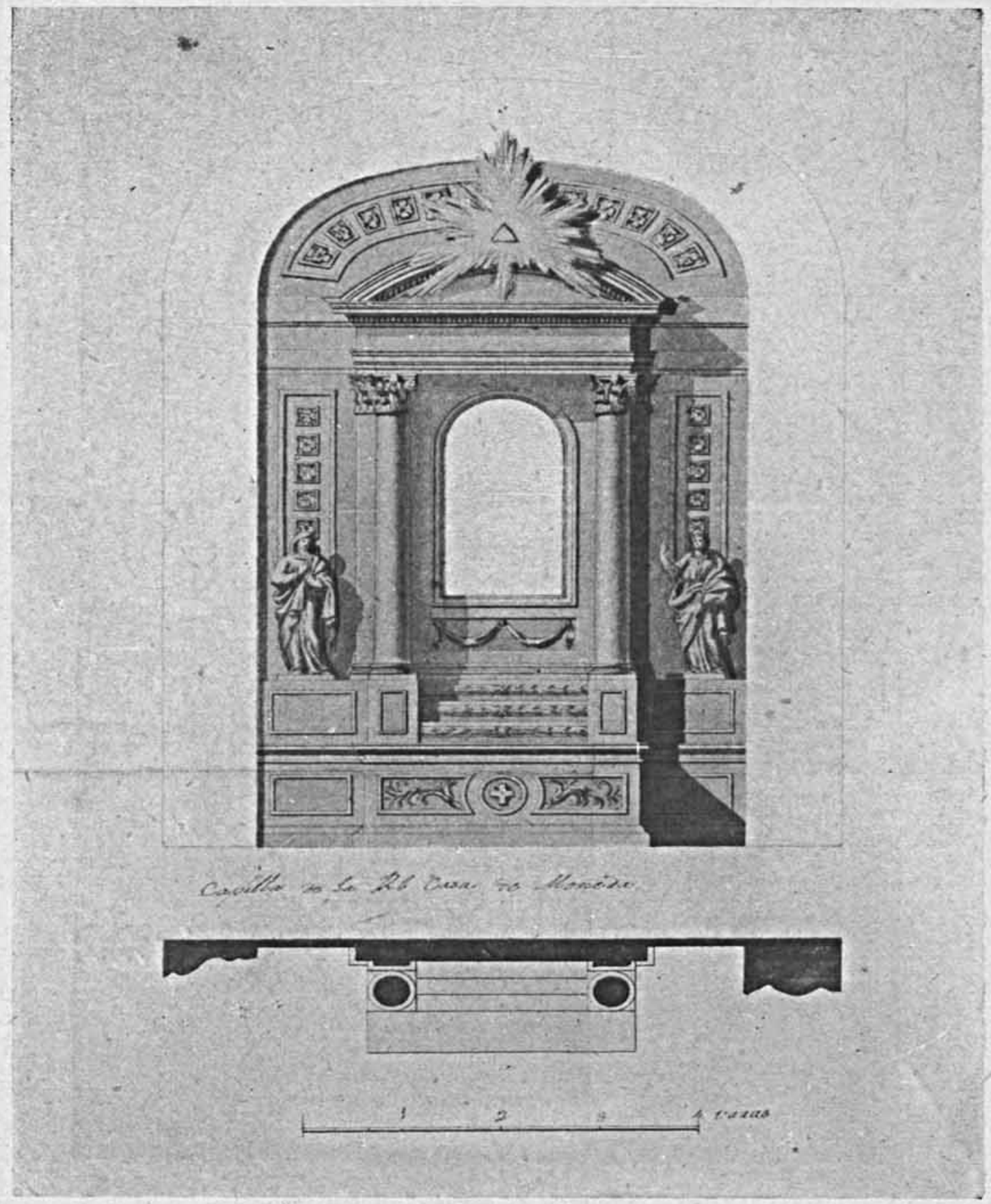

Fig. 8. Proyecto de altar para la Casa de Moneda. Planta y alzado 
DOI: http://dx.doi.org/10.22201/iie.18703062e.1946.14.414

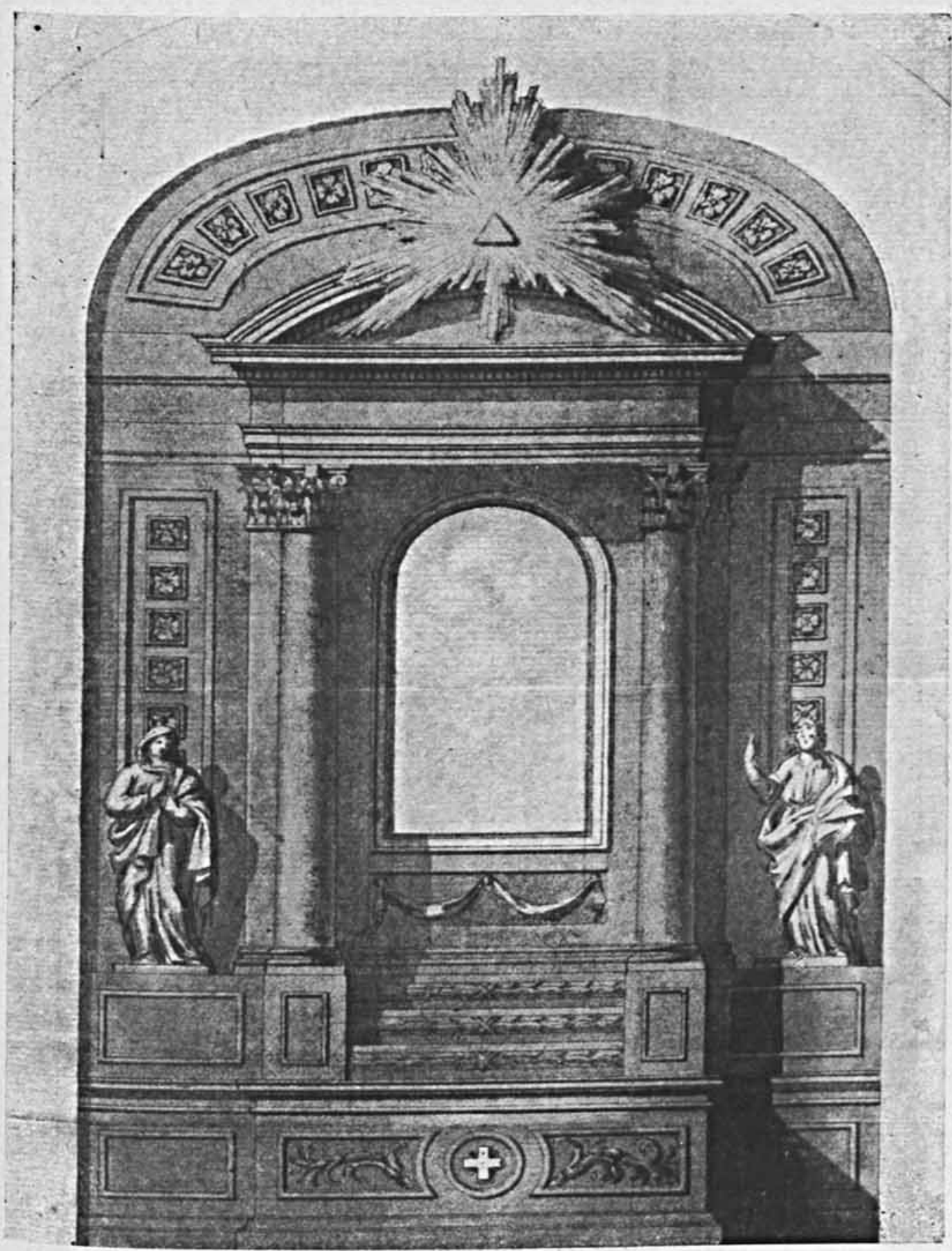

Fig. 9. Proyecto de altar para la Casa de Moneda. Detalle 


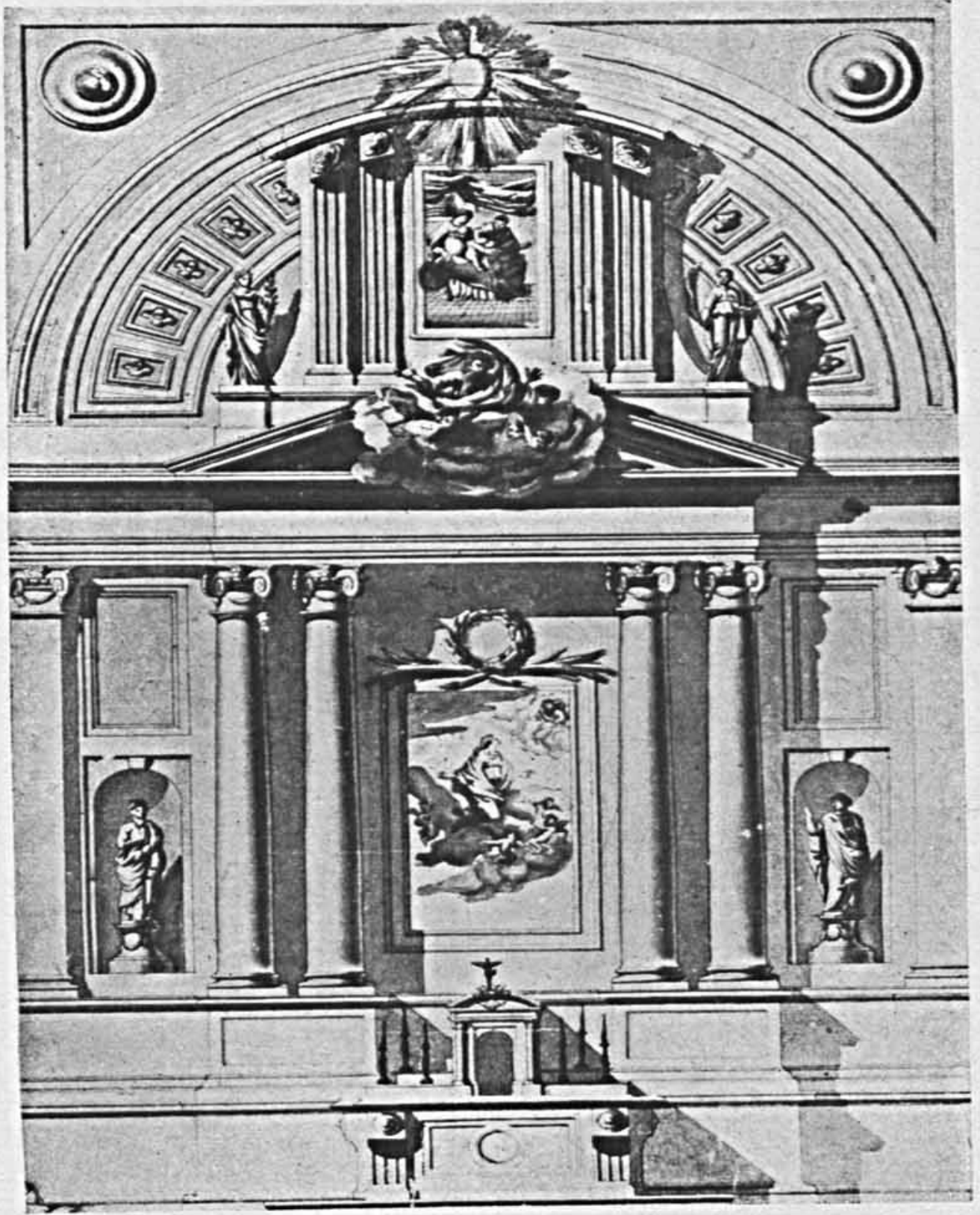

Fig. 10. Proyecto de altar 


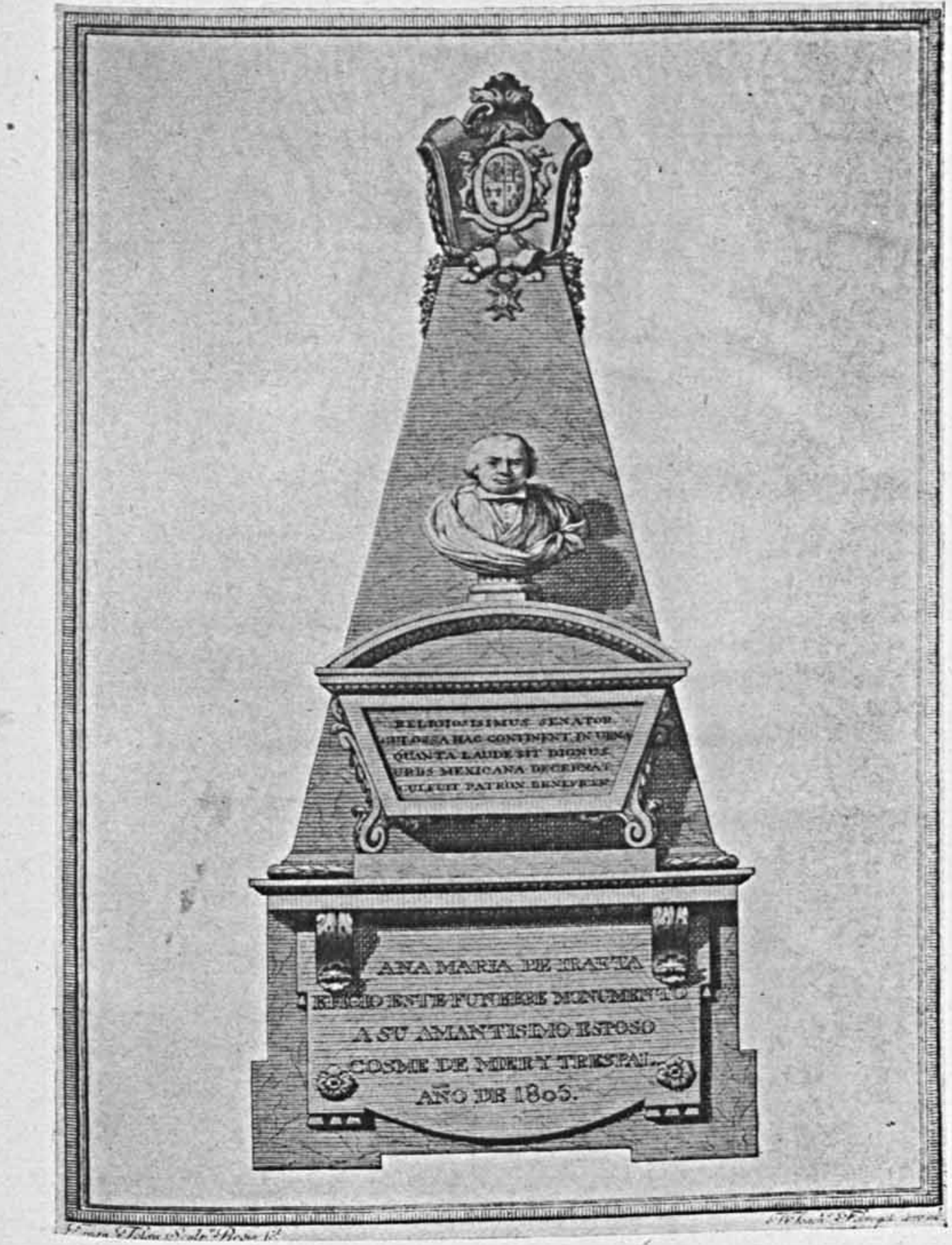

Fig. 11. Sepulcro del oidor Mier 
Caja ex-propiedad del tscubtory Arquirecto D Manuel Tolsa

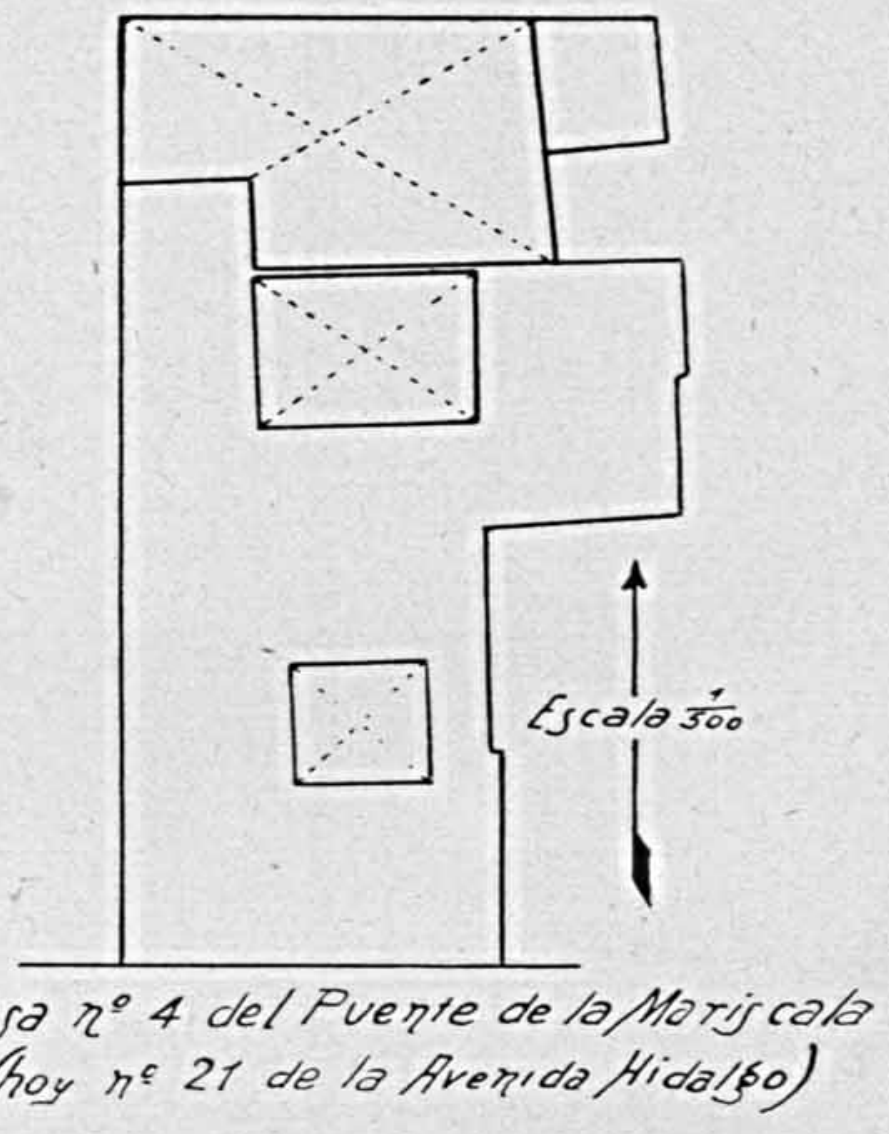

Fig. 12. Plano esquemático de la casa de Tolsá 


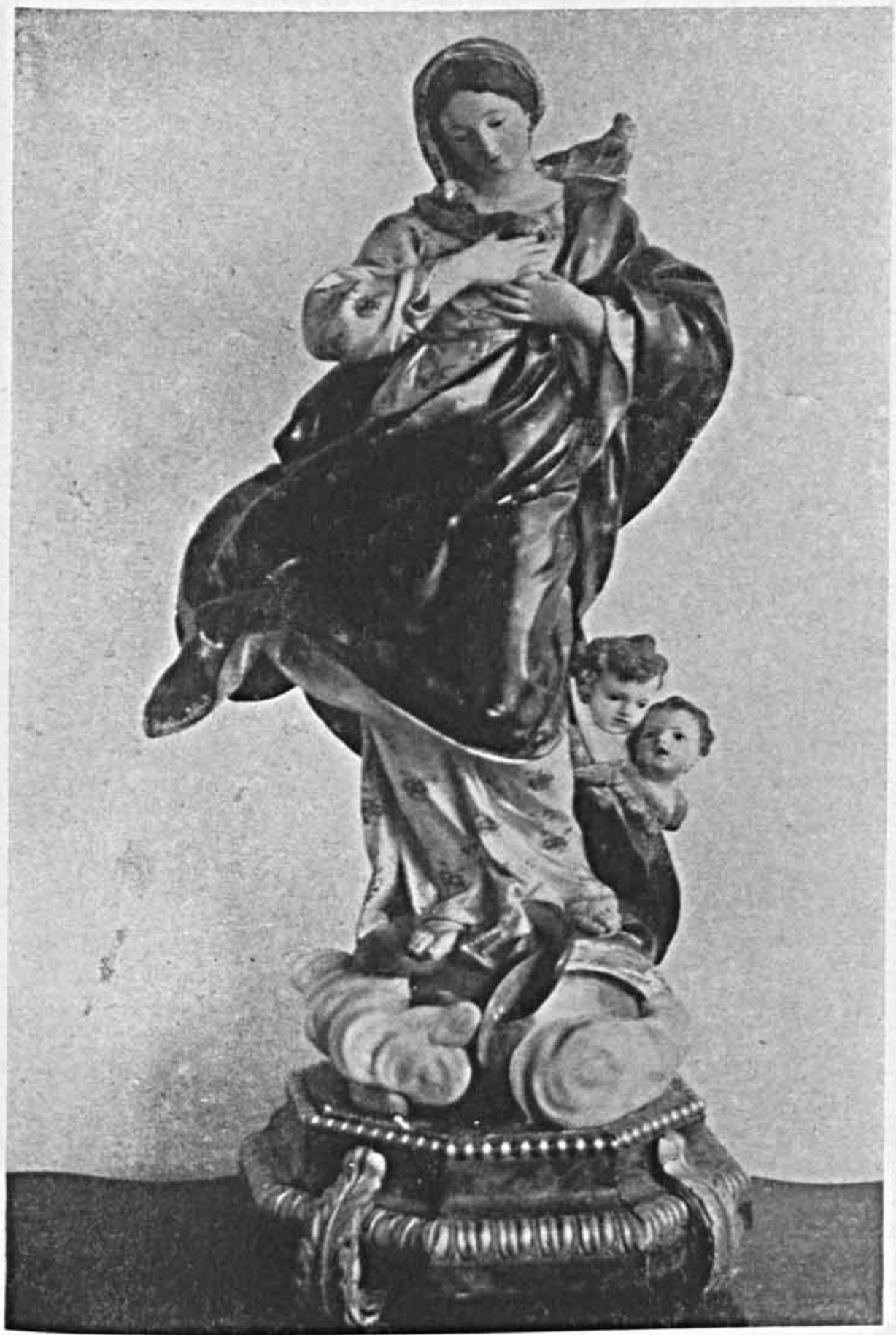

Fig. 13. Estatua de la Purísima 


\section{El. Sepulcro del Otdor Mirr}

La señora doña Ana María de Iraeta, al motir su esposo, el activo oidor don Cosme de Mier y Trespalacios, quiso inmortalizar su memoria, para lo cual publicó un libro y construyó un monumento funerario. El primero, aunque muy raro, existe; del segundo no quedan ni rastros.

El libro fué las Solemnes Exequias celebradas en la Iglesia del Tercer Orden de Nuestra Señara del Carmen de México, el día 6 de Noviembre de 1805, por el alma del Señor Don Cosme de Mier y Trespalacios, del Consejo de Su Majestad, Oidor Decano... etc., editado por don José Mariano de Zúñiga y Ontiveros, en el año de 1806. En él se describen las honras fúnebres del alto funcionario, $y$ en la Oración fünebre su biografia, interesante por los datos que nos brinda de sus aficiones de mecenas y el importante papel que ocupó en la superintendencia del Desagũe deI valle de México.

El sepuicro fué encargado, como es natural, al escultor de más renombre entonces, es decir, a Manuel Tolsá.

"Para perpetuar la memoria de un sujeto tan benemérito - se dice en el prólogo- se construyó un magnífico sepulcro en el templo de la misma Tercera Orden; se encargó su dirección al célebre don Manuel Tolsa, cuyo nombre sólo es ya bastante elogio, y es como sigue: sobre el pilar de dos varas de ancho que sostiene el arco del prebisterio, en el lado del Evangelio, está figurado un cuadro, y en él una pirámide trunca en aiusión a la temprana muerte del señor Mier. Ambas cosas unidas son hechas de escayola, intitando el verde jaspe de Granada, con tres pulgadas de relieve sobre el pilar. En la pirámide se ve colocada una lápida de jaspe rósado, y en ella, con letras de bronce dorado a fuego, la siguiente inscripción castellana :

ANA. MARIA. DE. IRAETA.

ERTGTO. ESTE. FUNEBRE. MONUMENTO.

A. SU. AMANTISTMO. ESPOSO.

COSME. DE. MTER. Y. TRESPALACIOS.

AÑo. DE. 1805.

"Sobre la misma lápida en unos canes y adomos de estuco dorado sienta tuna ligera cornisa de mármol blanco que sirve de sostener, con su saliente, una grada de jaspe negro, sobre la ctral está colocada una Uma. 
Sepulcral, formada de mármol blanco y negro, y es donde descansan las cenizas. En ella se vé, con letras iguales a las primeras, esta inscripción latina:

REIIGIOSISSIMVS. SENATOR.

CVIVS. OSSA. Hac. CONTINENTVR. IN. URNA.

QVANTA. LAVDE. SIT. DIGNVS.

URBS. MEXICANA. DISCERNAT.

CVIVS. FUIT. PATRONVS. BENEFICENTISSIMVS.

"Descansa sobre la Urna el busto del señor Mier, vestido de toga. Es por ahóra de estuco, interin se concluye el de bronce dorado a fuego. Finalmente, en el remate de la pirámide, se mira el escudo de sus armas, hecho también de estuco dorado."

Un precioso grabado, inserto antes de la Oración fúnebre, nos recuerda el sepulcro. Las firmas del grabado dicen: Eman. Tolsa Sculpr Regis $S c^{*}$ : Manuel Tolsá, Escultor Regio, esculpió. Por cierto que es ésta la única vez que se le califica con ese título. La otra es: J. Joach" Fabregat aere inc $c^{t}$ José Joaquin Fabregat grabó en cobre. La plancha tiene 16 centimetros de ancho por 27 de alto.

Parece que sólo hubo otro monumento funerario de este tipo en México en la época colonial, el de Hernán Cortés, en la iglesia del Hospital de Jesús, hecho en 1794 por el arquitecto José del Mazo, pero sin la riqueza ornamental ni la donosura de éste de Tolsá.

Ninguno de estos dos sepulcros existe ya. El de Cortés fué destruído por el temor a la ignorancia del populacho exaltado poco después de la Independencia, como es bien sabido; el de Mier por la ignorancia de los frailes carmelitas ante el temor de parecer anticuados cuando "renovaron" el Tercer Orden, hoy iglesia del Carmen.

\section{La Casa de Totsk}

Aún existe, reformada y destrozada, la casa en que vivió y murió Tolsá, construida por él. Fué el número 4 de la calle del Puente de la 
Mariscala, que corresponde actualmente a los números 21 a 27 de la avenida Hidalgo.

La fachada, con un piso más, agregado en este siglo, se limita por dos pilastras jónicas, entre las que van seis monótonos $\mathrm{y}$ sencillos balcones. Aún perdura la puerta, ancha, con jambas y dintel de piedra, moldurados, y la entrada, que desemboca al antiguo patio por dos severas pilastras. Los corredores del patio son volados, como los que hizo Tolsá para el palacio de los marqueses del Apartado. En el fondo hay una fuente, de dibujo neoclásico, de cantera, con mosaicos que quizás fueron puestos después.

Ahora es casa de vecindad y los patios lugares de desperdicios y bodegas.

En el plano que publico, copia esquemática del sacado hace años cuando fué vendida por los descendientes del artista, aparecen, de arriba para abajo, sobre la calle, un gran patio que ya no existe; luego el patio que puede verse todavía y en cuyo fondo está la fuente; el otro patio, pequeño, fué derribado para construir una casa moderna.

Los Canapes de da Seĩora NǴ̃̄ez

Poco sabemos de los muebles que diseñaba y decoraba Tolsá. Quizás algunas de las grandes mansiones nobiliarias que edificó en México esturieron también amuebladas por él. Por lo pronto tenemos una prueba en los canapés que hizo para la señora Núñez y Velarde, de Querétaro, cuyos documentos originales publico a continuación: 10

"Sra. Doña Ana Josefa Núnex y Velarde. Muy Sra. mia, queda en mi poder la pieza de cotense de cuarenta $y$ una varas y tercia, y luego que se corten todos los cojines avisaré el que falte. Tanto este como el Damasco para que no resulte sobrante ni de uno ni de otro.

"Los cojines se rellenarán de zerda como Ud. previene, pero dudo que se pueda conseguir por estar sumamente escaso este género.

"Nada me ha dicho Ud. sobre si quiere los cojines de los canapés que sean enteros de largo de cada uno o que vayan sueltos o divididos por asientos, de modo que sumidos formen el canapé. Tenga Ud. la vondad de avisármelo por ser cosa hurjente para cortarlos. Septien.

10 Agradezeo la copia de extos documentos al señor licenciado don Mannel 
"Ia muselina no es tan necesaria respecto que el sastre podrá acer la colgadura por otra cama de higual tamaño que yo le harmaré quando se quiera.

"Queda a la disposición de Ud., y sus P. B. (pies besa) este su Afmo. y Seg. Servidor.

"Casa de Ud. y Julio 29 de 1812."

\section{"Manuel Tolsá"}

‘Mi Sra Da Josefa Núñez y Belarde a Tolsa por lo siguiente:

"Por un Canapé grande de cinco asientos, dado de color de porcelana, con perfiles dorados y su cojín como otros anteriores que se le hicieron . . - . . . . . . . . . 100 ps. "Por un cajón grande p encajonarlo . . . . . . . . 11 ps. "Por dos mesas de vara en cuadro cada una, pintadas como los canapeses a 30 ps. cada una . . . . . . . . . . 60 ps. "Por un cajón encajonado de dhas . . . . . . . . . 6 ps. "Por seis cajones para encajonar tuna cama . . . . . . . 32 ps.

"(Se le bajaron 49 ps. y solo se pagaron 16)."

"Febrero 26 de 1813".

“Recibí. Manuel Tolsá (Rúbrica)."

No hay que olvidar que el Conde de Casa de Heras decia en 1817 : "todos los artefactos, desde el edificio grandioso hasta el mueble y utensilio doméstico menos considerado, recibieron de su ingenio nuevas y bellas formas, generalizando en todo y por todas partes el buen gusto, la hermosura, sencillez y máquinas ingeniosas para facilitar los trabajos". ${ }^{11}$

Por ser un documento inédito y mostrar a Tolsá una yez más en relación con la ciudad de Querétaro, cosa hasta hoy desconocida, publico la siguiente carta del archivo particular del marqués de San Francisco. "Sr. Lic. D. Francisco Azcárate-Muy Sor. mio y amigo. Ya sabe V. M. que desde el 28 de abril del año pasado el Tribunal de Minería me transfirió diez y nueve mil setecientos treinta y tres pesos que éste me debía de los treinta mil que debe la casa del Sr. Conde de Regla a dho Tribunal, cuya 
escritura de pago finalizó el término hace diez años, transfiriéndome igualmente el rédito que le correspondia por esta cantidad hasta que se verifique el pago. Sobre este particular hasta la presente no he querido hacer gestión porque me constan los atrasos y descalabros que han padecido y porque amo por todos títulos a los Sres. que la componen, pero mis apuros me obligan a no poder guardar un silencio que en otro tiempo sería dilatado, y así, en atención a mis escacezes le suplico interponga sus respetos con dichos Sres. a fin de que se me pague el rédito de año y medio que va a ser debengado el mes inmediato $y$ si en esta capital no hubiese proporción de verificarlo, que se me dé la correspondiente libranza para cobrarlo en Querétaro, asi como se ha hecho con otros afligidos como éste su afmo. amigo, Q. S. M. B. Manuel Tolsá. (Rúbrica.) Casa y Sbre. 7 de $815 . "$

\section{Las Pequeñas Purfimas}

Además de las grandes esculturas de Purisimas que existen en la Iglesia de la Profesa, de México, y en la catedral de Puebla, Tolsá hizo cuatro pequeñas réplicas, más o menos fieles, que se conservan en poder de los descendientes del marqués de Vivanco, aristócrata que, según tradición familiar, las mandó hacer al artista valenciano.

Son de pasta, es decir, de una mezcla de serrín muy fino, grenetina y albayalde. Esto hace sospechosa la factura de las imágenes por mano del propio Tolsá, y hace pensar en sus discípulos, pero la constante tradición de familia, el saber que Tolsá trabajó en yeso e "inició una clase de decoración en estuco", así como de que esculpió algunas estatuas pequeñas, dan validez a lf atribución que hago. Además la extraordinaria elegancia con que están trabajadas inclina también a recordar a Tolsá. Se les puede aplicar la frase que Moreno Villa dedicó a la Purísima de la Profesa: "tan ondulada y rococó, tan pintoresca, tan desprendida de una Purisina del Tiépolo por su alegría y vuelo de paños..."12 Cualidades todas que se afinan en estas virgenes hogareñas, hechas para verse de cerca.

Reproduzco la escultura que pertenece a la señora doña Carmen Rubio y Morán de Gómez, hoy en San Luis Potosí. Mide ochenta centímetros, y el pie de madera, trece. La actitud de las manos es idéntica a las de la Virgen de la Profesa, así como los colores del traje y del manto y los di-

11 Anales 12, pág. 41.

12 La Escultura Colonial. México, 1942. pág. 74. 
bujos del estofado; el rostro voltea, sin embargo, al lado derecho, y de ese lado también se revuela el manto. Las preciosas cabecitas de los querubines están a la izquierda.

Aún conserva esta imagen su espléndido nicho dorado, de estilo neoclásico, forrado de papel tapiz rojo.

UN ERror Secular

Ya casi van cien años de estar repitiendo, con Ribera Cambas, Marroqui, Revilla, etc., que los altares y escuituras de las capillas de Guadalupe y de la Cena, de la catedral de México, fueron hechas por Tolsá.

Pero no es así. Por la Cuenta y Comprobantes de la reedificación de las dos capillas de Ntra. Sra. de Guadalupe y la Cena, de la pertenencia de la M. 1. Archicofradía del SSmo. Sacramento de esta Santa Iglesia, del año de 1812, que existe original en el archivo del Colegio de las Vizcaínas, sabemos que el arquitecto que renovó las capillas fué José del Mazo y Avilés, de 1808 a 1811. El pintor fué José María Vázquez, que hizo tres cuadros: la Virgen de Guadalupe, la Santa Cena y el Divino Salvador.

El escultor fué Clemente Terrazas. Se lee en la Cuenta: "Por 2,580 pesos pagados al escultor Clemente Terrazas por 17 imágenes o estatuas para los seis altares de las dos capillas", y luego explica el imaginero, en el recibo, cuáles fueron las estatuas: "A don José Martínez de los Rios por las imágenes que he trabajado para las dos capillas de Ntra. Sra. de Guadalupe y la Cena de esta Sta. Iglesia, debe, por las imágenes de Sr. San Joaquín, Santa Ana, San Juan, San Zacarias, Santa Isabel, San Estanislao y San Juan Francisco Regis, para la capilla de Guadalupe, a 60 pesos; por las imágenes de San Agustín, Santo Tomás de Aquino, San Francisco, San Buenaventura, San Roque, Santo Domingo, San Vicente Ferrer y San Jacinto, a 160 pesos, son dos mil y quinientos veinte pesos. México. Mayo 10 de 1811. Clemente Terrazas. (Rúbrica.)"

Sólo esto sabemos, por lo pronto, de este desconocido escultor, discípulo de Tolsá. Quizás fué padre de Francisco Terrazas, escultor de las imágenes del ciprés que hizo dón Lorenzo de la Hidalga para la catedral en 1845, así como de la Dolorosa de la capilla de la Cena, que le mandó esculpir el emperador Maximiliano para la capilla del entonces Palacio Imperial. 